\title{
BEHAVIOR OF SOME RICE GENOTYPES AS AFFECTED BY SOME MAJOR DISEASES INFECTION UNDER DIFFERENT CONDITIONS. \\ Hammoud, S. A. A. ${ }^{1}$ and W. S. Gabr ${ }^{2}$ \\ ${ }^{1}$ Rice Department, Filed Crops Research Institute, Agriculture Research Center, Cairo, Egypt \\ 2 Rice Disease Department, Plant Pathology Research Institute, Agriculture Research Center, Cairo, Egypt. Email: Waelgabr22@gmail.com.
}

\begin{abstract}
The present study was carried out at Rice Research and Training Center farm and Plant Pathology Department, Sakha, Kafr El-Sheikh, Egypt. During 2012 and 2013 successive seasons to screen and evaluate some exotic and local seven verities along with the best 13 selected lines developed from the diallel cross which done during 2006. selection was done from F2 up to F5. Screening testing was made for the 20 rice genotypes against the major diseases infesting rice in Egypt such as, blast, brown spot, bakanae and white tip nematode diseases. Randomized complete block design with three replicates was used under field condition to estimate yield and its attributes as well as the reaction of the different studied diseases. Twenty entries/genotypes were tested under greenhouse and field conditions. Results indicated that, SP- 70, IRAT 112, IR 65610-105-2-5-2-2-2, GZ 7769-2-1-1-2, SK-1017-16, SK-101-7-17, SK-101-7-25, SK-101-7-26, SK-101-7-35, SK-101-7-37, GG-46-61, SK-101-Pa-1, SK-101-Pa-3 and SK-101-Pa-4 were resistant to all rice blast races under this study. On the other hand, GG-24-1-2 and GG-42-2-6 genotypes were susceptible to one race, while GG-24-1-2 showed moderate resistance for the two races. For brown spot results indicted that, HR 4856, IRAT 112, SK-101-Pa-1and Sakha 101 gave the highest infection percent and severity. On the other hand, GG46-6-1, SK-101-7-26, GG-42-1-2 and SK-101-7-35 gave the lowest infection percent and severity. For bakanae disease, Sakha 101 as a susceptible cultivar gave the highest percentage and severity infection values of 76.08 and $18.66 \%$ respectively, followed by GZ 7769 and Sakha 104 (65.74, $15.33 \%$ and 47.57, $13.15 \%$ respectively). On the other hand, all entries gave the lowest infection of bakanae rice disease under natural infection. For white tip nematode, the genotypes of GZ 7769, HR 4856, Sakha 104, SK-101-Pa-3, Sakha 101 and SK-101-7-26 gave the highest infection. While the genotypes, SP-7, SK-101-7-16, SK-101-7-17, SK-101-7-35, SK101-7-37, GG-42-6-1, GG-42-1-2, GG-42-1-6 and SK-101-Pa-4 gave the lowest infection values. For Vitavax as recommended fungicide to control rice Bakanae disease and sodium chloride treatment were the highest efficiency to control the bakanae disease under natural and inoculated conditions. Results show that some genotypes could be used i.e. SP-70 and SK 101-7-16 and SK 101-7-17 and SK 1017-35 and SK 101-7-37 and GG-46-6-1 and GG 42 - 1-2 and GG 42-1-6 and SK 101$\mathrm{Pa}-4$ as the sources of diseases resistance in rice breeding programs.
\end{abstract}

Keywords: Rice, Rice blast disease, Brown spot, Bakanae, White tip nematode.

\section{INTRODUCTION}

Rice is the second most important cereal crop in the Afro-Asian continental level. It constitutes the essential food for over half $(54 \%)$ of the world's population FAO (2012). In Egypt, rice is annually grown in more than one million feddans, mostly in the Northern part of the Nile Delta. Egypt is 
considered as one of the countries having the highest average yield of rice in the world (Annual Rice National Campaign Report (2012). Breeding for resistance is the most economic way within the integrated disease management strategy. However, the breakdown of major gene resistance of the new cultivars is known to occur as the area of the cultivar increased. A new cultivar is known to remain resistant for a period of time between 2 and 6 years Kiyosawa (1974). Rice crop is a host of many biotic agents in many tropical countries, complicated situations had resulted in harmful effects due to such biotic agents, thus reducing yields to appreciable levels. In Egypt, the major rice diseases are blast (Pyricularia grisea Cav.), brown spot (Helminthosporium oryzae Breda De Hann), , foot rot or bakanae disease (Fusarium moniliforme or Gibberella fujikurol), and white tip nematode (Aphelenchoides bessyi). However, rice diseases (especially rice blast) reduce rice production by about $5 \%$ in normal or mildly infected seasons. In epidemic seasons, yield losses may reach as high as $30-50 \%$ Sehly et al. (2002). Field leaf resistance can be partitioned into a few components of slow- blasting resistance such as lesion size or lesion density Veillet et al. (1996). These components are usually assessed in the greenhouse by inoculation with compatible blast isolates, and they could be used advantageously as selection criteria. In addition, partial resistance can usually be considered as a quantitative trait Wang et al. (1994) and Roumen (1993). The relative importance of line or hybrid breeding from a segregating population theoretically depends not only on the ratio between the line and hybrid genetic variances Ghazanfar et al. (2009), but also a break-down of the genetic variability of both kinds of varieties would help to better understanding of the inheritance of partial resistance and, furthermore, compare genetic gains, following different selection methods. The description of genetic variability in non-allelic population, with different levels of inbreeding, is very complex Ghazanfar et al. (2009), Harris (1964) and Cockerham (1983). The brown spot disease of rice caused by Helminthosporium oryzae is severe problem of rice under dry conditions. Pathogen of rice brown spot infests rice and many other field crops causing severe losses in fodder and grain yield. In rice the pathogen infects the coleoptiles (causes blighting), leaves (with oval, dark brown to purplish-brown spots) and rigorous damages the photosynthetic activities and ultimately kills the leaf. It has been documented that rice cultivation under aerobic conditions resulted in $27.5 \%$ yield reduction over flooded rice due to brown spot disease Patel et al. (2010). The severity of brown spot disease can be managed through development of resistant lines Mew et al. (1991) and Bonman et al. (1991). The economic analysis suggests that modern varieties with disease resistance contribute $7 \%$ to $10 \%$ yield gain in rice production Evenson et al. (1998). The screening of aerobic rice for disease resistant lines under irrigated conditions may be misleading as the disease sternness is not hostile and belligerent under such conditions.

Bakanae disease is a seed-borne as well as soil-borne disease. When seeds of rice plants are infected by the fungus, the most characteristic symptoms of the disease is the appearance of tall thin plants, markedly overgrowing than their uninfected neighbours. The active metabolic product of the 
pathogen is gibberellins which were isolated and proved to play an important role in the pathogenicity of this organism by many workers Kumar (1984), Ou (1985), Li and Luo (1997), Jeff (2001), Rood (2004) and Li et al. (2005). Identification of resistant lines and varieties is very important in integrated disease management program.

The white-tip disease caused by Aphelenchoides besseyi was first discovered in Japan during 1940. Ou (1985) has provided a good review of this disease. The common name of the pest as white-tip nematode refers to the characteristics whitening of $3-5 \mathrm{~cm}$ of the rice leaf tip. The white tip nematode is reported form deep-water as well as upland rice in Africa, north America, Asia (including India and Bangladesh), Pacific and East European countries. This study was conducted to evaluate and screen some rice genotypes against some major diseases infecting rice in Egypt to be used directly or to be used as a donor for specific disease or multi disease resistant rice lines.

\section{MATERIALS AND METHODS}

Experiments were carried out at the Rice Pathology Lab., greenhouse and Rice Research and Training Center Farm (RRTC), Sakha, Kafr ELSheikh, Egypt during eight successive seasons from 2006 to 2013. Seven parents; Sakha101, SP-70-6-20, IRAT 112, IR 65610, Sakha 104, HR4856 and GZ 7769 were used to establish the half diallel analysis which used in this study. Characteristics of the seven rice cultivars studied are given in Table (1). In 2006 the seven rice parents were grown in three successive sowing dates at fifteen-day intervals to overcome the differences in flowering time of these parents. Single seedling of each parent was transplanted 30 days after sowing in the permanent field, each in five rows. Each row was five meters long and contained 25 hills. The experiment was designed in a randomized complete block design with three replications in 2007. twenty one genotypes from $\mathrm{F} 1$ generation were growing in three rows each row five meters long and on single plant basis. General and specific combining abilities are estimated by Griffing,s approach method 2 model 1 (1956). in this approach the variances due to general and specific combining ability are estimated, which in turn, would be translated into general components such as additive, and non-additive gene actions, respectively, under certain assumptions. The scheme, breeding process and details of this study was illustrated in Table (2).

During 2012 and 2013 seasons a total of 13 promising lines selected according to phenotypic acceptability and yield according to breeding objectives dependins on agronomic characters including (plant height, flag leaf area, duration, panicle numbers, panicle length, no. of filled grains/panicle, 1000 grain weight, hulling\%, milling \%, grain yield $(\mathrm{T} / \mathrm{h})$ and diseases incidence are, ( blast infection in the field and greenhouse, brown spot severity, white tip nematode \%, bakanae incidence either for noninoculated or inoculated seeds compared with treated seeds with Vitavax $2 \mathrm{~g} / \mathrm{Kg}$ or sodium chloride $50 \mathrm{~g} / \mathrm{LL}$ ) and collected data around reaction of genotypes to bakanae disease under lab condition for healthy plants before inoculated and after inoculated. 
Table (1): Names, pedigree and origin of some selected genotypes tested.

\begin{tabular}{|c|l|c|c|}
\hline No. & Genotype & Pedigree & Origin \\
\hline 1 & Sakha 101 & Giza 176 / Milyang 79 & Egypt \\
\hline 2 & SP- 70 & Sakha 101 (HR 4856 X Sakha 101) & Egypt \\
\hline 3 & IRAT 112 & IRAT 13 / DOURADO PROECOCE & IVORYCOAST \\
\hline 4 & IR 65610-105-2-5-2-2-2 & IET 10364 / IR 54950-181-2-1-2-3 & IRRI \\
\hline 5 & Sakha 104 & GZ 4096 / GZ 4100 & Egypt \\
\hline 6 & HR 4856-1-1-1-1-2 & IRI 346 / HR 3499 & South KOREA \\
\hline 7 & GZ 7769-2-1-1-2 & GZ 5385 / Akiyutaka & Egypt \\
\hline 8 & SK-101-7-16 & Sakha 101 / GZ 7769-2-1-1-2 & Egypt \\
\hline 9 & SK-101-7-17 & Sakha 101 / GZ 7769-2-1-1-2 & Egypt \\
\hline 10 & SK-101-7-25 & Sakha 101 / IRAT112 & Egypt \\
\hline 11 & SK-101-7-26 & Sakha 101 / IRAT112 & Egypt \\
\hline 12 & SK-101-7-35 & GZ 7769-2-1-1-2 / IRAT112 & Egypt \\
\hline 13 & SK-101-7-37 & Sakha 104 / IRAT 5600 & Egypt \\
\hline 14 & GG-46-6-1 & Sakha 104 / IR 165000 & Egypt \\
\hline 15 & GG-42-1-2 & Sakha 101/ IR 165000 & Egypt \\
\hline 16 & GG-42-2-6 & SP- 70 / IR 165000 & Egypt \\
\hline 17 & SK-101-Pa-1 & Sakha 104 /x HR4856 & Egypt \\
\hline 18 & SK-101-Pa-3 & GZ 7769-2-1-1-2 / HR 4856 & Egypt \\
\hline 19 & SK-101-Pa-4 & SP-70 / HR 4856 & Egypt \\
\hline 20 & SK-101-Pa-6 & Sakha 101 x/ HR 4856 & Egypt \\
\hline
\end{tabular}

Table ( 2 ): Genetic materials developed the through scheme of the study started from 2006 up to 2013 seasons.

\begin{tabular}{|c|c|l|}
\hline No. & Entry & Process \\
\hline 1 & 2006 & Crossing among 7 parents following half diallel cross system \\
\hline 2 & 2007 & Growing F1 generation in the field \\
\hline 3 & 2008 & $\begin{array}{l}\text { Growing F2 Generations and start selection depended on } \\
\text { breeding objectives }\end{array}$ \\
\hline 4 & 2009 & Growing 21 family each families as a F3 generation \\
\hline 5 & 2010 & $\begin{array}{l}\text { Selected the best excellent plants from } 21 \text { populations and } \\
\text { growing each plant } 3 \text { rows each row } 5 \text { meter length as F4. }\end{array}$ \\
\hline 6 & 2011 & Selected the best 13 populations genotyps \\
\hline 22012 & Evaluated 13 promising lines \\
\hline 2013 & Evaluated 13 promising lines \\
\hline
\end{tabular}

Field evaluation (diseases):

Blast evaluation:

A- At seedling stage (in blast nursery test):

Rice genotypes were evaluated for seedling reaction under blast nursery (natural infection) at three locations i.e. Sakha (Kafr El-Sheikh), Gemmiza (Gharbia) and Zarzora (Beheira) governorates, with three replications for each. Seedbed was prepared, manure fertilizer was added 
during land preparation $\left(20 \mathrm{~m}^{2} / \mathrm{ha}\right)$. Each entry was planted in 5 rows of 50 $\mathrm{cm}$ long and $15 \mathrm{~cm}$ apart. Giza 159 was used as a susceptible check and border as a source of blast inoculums. While, Giza 177 was used as resistant check. The resistant and susceptible checks were cultivated as alternatively with five rows of each tested entry. The sowing date was done in the first week of July in both 2012 to 2013 growing seasons. Natural infection was developed and plants were scored 30-45 days after sowing, using the (0-9) scale SES of IRRI (1996) as follow:

1-2 = resistant $(\mathrm{R})$

$3=$ moderately resistant (MR)

4-6 = susceptible $(S)$

7-9 = highly susceptible (HS.

\section{B-At adult stage:}

One hundred leaves were randomly collected from each genotype to determine leaf blast infection with fifteen days intervals started from the appearance of primary infection. Percentage of the infected leaves was calculated, while severity of infection was estimated by counting the total number of infection type (4 lesion type or more) blast lesions/100 leaves. Neck rot infection was estimated by collecting one hundred panicles from each plot one week before harvesting. The severity of neck rot infection was calculated using the formula adopted by Townsend \& Huberger (1943).

\section{Brown spot evaluation:}

Samples of rice leaves were collected at maximum tillering stage for the tested genotypes. Total number of lesion of brown spots were calculated in one hundred leaves, which were randomly collected from each plot and recorded as severity of infection SES of IRRI, 1996 ). After harvest, samples of one hundred grains were taken for estimating the discolored grain percentage.

\section{Bakanae disease evaluation:}

Seven rice cultivars as well as thirteen lines were treated with spore suspension of Fusarium moniliforme fungus, sodium chloride solution and Vitavax as recommended fungicide to bakanae disease incidence. Nursery beds of the rice entries were seeded as a rate of $60 \mathrm{Kg}$ grains/feddan in $15^{\text {th }}$ of May, and the seedlings were transplanted 30-days after sowing at plot size of $3 \times 3.5 \mathrm{~m} 2$ as $20 \times 20 \mathrm{~cm}$, with four plants/hill. The nitrogen fertilizer was added as Urea $(46.5 \% \mathrm{~N})$ at the rate of 60 units of nitrogen per feddan. Two thirds of nitrogen dose were incorporated to the top $15 \mathrm{~cm}$ of the dry soil as a basal application before transplanting, while, the last third was added 30-days after transplanting. Symptoms of bakanae disease became visible about 15 to 20 days after planting. Samples and disease reactions were taken at the nursery (25-30 days after sowing) to ensure the full appearance of bakanae rice disease symptoms. Plant growth parameters i.e., the infected plants (\%), dead plants \% due to infection, were recorded.

\section{White-tip nematode evaluation and screening:}

The rice entries were evaluated to white tip nematode disease, the rice samples were collected, as one hundred flag leaf randomly collected from each plot before heading to determine severity of infection according to leaf area damage as SES of IRRI (1996) as follow. 


$\begin{array}{ll}<1 \% & \text { resistant } \\ 1-30 \% & \text { moderately susceptible } \\ >30-60 \% & \text { susceptible } \\ >60 \% & \text { highly susceptible. }\end{array}$

Percentage of infection was estimated by using the following formula:

Percentage of infection $=\frac{\text { Number of infected hills } / \mathrm{m}^{2}}{\text { Total number of rice hills } \mathrm{s} / \mathrm{m}^{2}}$

\section{Laboratory and greenhouse experiments: For blast disease:}

Rice entries, eight international differential varieties Atkins et al. (1967) and ten Japanese differential varieties Yamada et al. (1976) were inoculated with blast isolates in greenhouse conditions to evaluate, determined physiological blast races, and effective resistance genes. Plastic trays

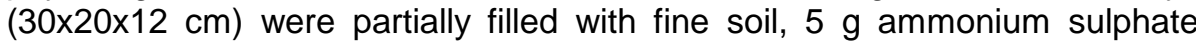
were added to each tray. Each tray was planted with 16 entries, and two rows in the ends of each tray as a susceptible check variety Giza 159. Plants were inoculated at 3-4 weeks after sowing. Single isolates were purified and grown on (200 g banana, $15 \mathrm{~g}$ glucose, $20 \mathrm{~g}$ agar / medium) for spore production. Two hundred $\mathrm{ml}$ of spore suspension was prepared from each isolate adjusted to $5 \times 10^{4}$ spores $/ \mathrm{ml}$. Twenty five isolates each season were inoculated, each isolate was sprayed using electrical spray gun. Plants were left in cages for 24 hours with $100 \% \mathrm{RH}$. Plants were moved to the incubation room supplied with automatic system for temperature adjustment, between $25-30^{\circ} \mathrm{C}$; relative humidity was maintained at about $100 \%$ by fine sprinklers. Seven days after inoculation, typical blast lesions appeared and scored using the 0-9 scale SES of IRRI (1996).

\section{For Bakanae disease:}

\section{Isolation and identification of bakane:}

Diseased specimens were collected from different rice fields, cut into 1 to $2 \mathrm{~cm}$ pieces, sterilized with immersing in $0.5 \%$ sodium hypochlorite solution $(\mathrm{NaOH})$ for two minutes, rinsed twice with sterilized distilled water and then placed onto potato dextrose agar medium (PDA). Plates were incubated at $27 \pm 2{ }^{\circ} \mathrm{C}$ for 5 to 7 days and the developed fungus was purified using single spore or hyphal tip techniques according to Hansen (1926). The different isolates were identified according to the morphological characteristics and microscopic examination using the key of imperfect fungi Nelson et al. (1983) and Summerell et al. (2003).

\section{Pathogenicity test for bakane disease:}

Seven genotypes i.e Sakha101, SP-70-6-20, IRAT 112, IR 65610, Sakha 104, HR4856 and GZ 7769 as well as thirteen lines were infected with the most aggressive Fusarium moniliforme isolates were studied in $15 \times 15 \mathrm{~cm}$ pots. One hundred grains from each rice genotypes was soaked in Fusarium moniliforme spore suspension $\left(4 \times 10^{5}\right.$ spores $\left./ \mathrm{ml}\right)$ for $48 \mathrm{~h}$. and incubated for $48 \mathrm{~h}$. at $35^{\circ} \mathrm{C}$. Other one hundred grains from each rice entry was soaked in distilled water for $48 \mathrm{~h}$. and incubated for $48 \mathrm{~h}$. at $\left(35^{\circ} \mathrm{C}\right)$ as cheek. The 
treated rice genotypes were cultivated in pots as $15 \times 15 \mathrm{~cm}$ diameter with three replications and kept in greenhouse at $30-35^{\circ} \mathrm{C}$. The fertilization with urea $46.5 \% \mathrm{~N} \mathrm{3g} /$ pot was applied one time. The number of infected plants was recorded 30 days after sowing. While, shoot and root length and fresh and dry weight were recorded 15 days after sowing at lab.

\section{RESULTS AND DISCUSSION}

The differences between twenty one genotypes and F1 generation were firstly tested in 2006 season using the ordinary analysis of variance. If the genotypes mean squares are found to be significant, there is need to proceed for further analysis. In order to obtain information about the portion of additive and non-additive gene a clion involved in the inheritance of the characters studied, Griffins approach (1956) method in F1 was generation was used, in this method the variance due to general and specific combining ability were estimated which, in turn, would be translated into genetical components. i.e. additive and non-additive gene actions respectively. In 2008 started selection in F2 generation according to breeding objectives. In 2012 and 201313 promising lines were evaluated obtained from excellent 21 genotypes and recorded data for agronomic characters and diseases infection according to standard evaluation system 2010 season during. For better representation and discussion of the results obtained here in it would be preferred to outline these results into two main parts i.e. agronomic and diseases infection and scoring.

1-Agronomic characters

1-1-Mean performance

Mean performance for thirteen rice genotypes of some agronomic characters at the two years and their combined data are presented in Table (3). Mean performance of all studied triats of their promising lines had a wide range of variability. This wide range was reflected in variation among tested genotypes. The low values of plant height and duration would be of interest under investigation from the breeders point of view Hammoud (2012). For plant height three lines exhibited shorter plant higher i.e, SK 101-101-7.17, SK 101-Pa-1 and SK 101-7-35 at the two years and their combined data respectively. For the duration, two promising lines SK 101-Pa- 3 and SK-101$\mathrm{Pa}-3$ were found to be early duration ranged from 119.3 to 124.33 day at the two years and their combined. Concerning yield and its components and grain quality the highest values are preferred from the breeder point of view. Regarding flag leaf area, panicle length and no. of filled grains, panicle number were found to be higher values for two crossing GG-46-6-1 and GG42-2-6 derived from crosses between Sakha 101 and Sakha 1204 with IR 16500 (supper rice) but gave low 1000-grain weight and grain quality tested. As for 1000-grain weight two hybrid combinations gave the highly weight grains SK 101-7-35 and SK 101-Pa-6. for grain yield t/h. two elite SK 101-725 and SK 101-7-35 gave the highest values for grain yield $t / h$. at the two years and their combined data. For grain quality tested two promising lines SK 101-7-35 and SK 101-Pa-6 showed high hulling but the last one gave the highest milling \%. 
Hammoud S. A. A. and W. S. Gabr

3 
J. Plant Prot. and Path., Mansoura Univ., Vol. 5 (9), September, 2014

3 
Hammoud S. A. A. and W. S. Gabr

3

880 


\section{Blast Resistance:}

Twenty entries/genotypes were tested under greenhouse and field conditions. The results in Tables (4\&5) indicated that, SP- 70, IRAT 112, IR 6560, GZ 7769-2-1-1-2, SK-101-7-16, SK-101-7-17, SK-101-7-25, SK-101-726, SK-101-7-35, SK-101-7-37, GG-46-6-1, SK-101-Pa-1, SK-101-Pa-3 and SK-101-Pa-4 were resistant to all rice blast races under this study. On the other hand, GG-24-1-2 and GG-42-2-6 genotypes were susceptible of one race, while GG-24-1-2 showed was moderately resistace for the two races. The susceptible checks (Sakha 101 and Sakha 104) were highly susceptible under greenhouse and field conditions. Gabr (2004) found that varieties Giza Sakha 101 and Sakha 104 were susceptible to 20 blast pathogen isolates in a greenhouse test. They also found that 9 of 27 entries were susceptible to one or more of the 20 purified isolates tested.

Concerning natural infection under field conditions, in the first season (2012), data in Table (4) show that sixteen entries were resistant and four entries were susceptible. In the second season (2013), fifteen entries were resistant and five were susceptible to leaf blast under blast nursery tests. The check performed as highly susceptible to blast. Kozaka (1965) and Chen (1989) observed that virulent strains were existed for all the identified genes of vertical resistance and most of the strains possessed virulent genes, which were not necessary for their survival. To avoid this risk, it is important to involve field resistance in the gene background of resistant varieties. Sanghera et al. (2011) evaluated 31 rice cultivers under field condition and found eight as resistant, ten moderately resistant, ten susceptible and three were highly susceptible.

\section{Brown spot screening:}

The present study was carried out to evaluate some entries to brown spot disease the results in Table (6) indicated that, HR 4856, IRAT 112, SK101-Pa-1and Sakha 101 gave the highest infection percent and severity. On the other hand, GG-46-6-1, SK-101-7-26, GG-42-1-2 and SK-101-7-35 gave the lowest infection percent and

severity.

\section{Bakanae disease:}

Results in Tables (7\&8\&9) indicated that Sakha 101 as a susceptible cultivars gave the highest percentage and severity of infection of 76.08 and $18.66 \%$ respectively followed by GZ 7769 and Sakha 104; 65.74, $15.33 \%$ and $47.57,13.15 \%$ respectively. On the other hand, all entries gave the lowest infection of Bakanae rice disease under natural infection Concerning artificial inoculation under lab. conditions Table (8) results indicated that Sakha 101 gave the highest infection under non-inoculated and inoculated conditions (1.667 and $89.33 \%$ respectively) while, Sakha 104 gave the lowest infection under both non-inoculated and inoculated (0.767 and 25.67 $\%$ respectively). For Vitavax as recommended fungicide to control rice Bakanae disease and sodium chloride treatment gave the highest efficiency to control the bakanae disease under natural and inoculated conditions.

Bakanae is a seed-borne as well as soil-borne disease. When seeds of rice plants are infected by the fungus, the most characteristic symptoms of the disease is the appearance of tall thin plants, markedly over-growing than 
their uninfected neighbors. The active metabolic product of the pathogen is gibberellins which was isolated and proved to play an important role in the pathogenicity of this organism by many workers Kumar (1984), Ou (1985), Li and Luo (1997), Jeff (2001), Rood (2004) and Li et al. (2005). Identification of resistant lines and varieties in very important in the integrated disease management program. Tasleem et al. (1999) screened forty rice varieties/lines under infested field conditions during 1995-97 against bakanae disease. Six varieties/lines (IR 6, IR 8, IR 9, KS 282, PK 3717-9 and Shadab) were resistant, ten varieties $(49643,49730,49770,49931,52616,52788$, Jhona 349, Pk 3717-12, Pk 3355-5-1-4 and Pk 3300-12-2) displayed a moderately resistant reaction, while eight, eleven and five genotypes showed moderately susceptible, susceptible and highly susceptible reactions, respectively. Khan et al. (2000) found that most of Basmati rice varieties cultivated in Pakistan were susceptible to bakanae disease and the fungus induced serious losses in rice crop in 1998.

Control of the disease through chemotherapy is receiving much attention as a result of its efficacy, and not having any deleterious effect on the vegetation and other components of the ecosystem. Currently, several fungicides have been employed in controlling the disease Aurangzeb et al. (1998), Biswas and Das (2002), (2003), Aurangzeb et al. (2003), Kabir et al. (2006) and Bagga and Sharma (2006).

Different seed treatment fungicides i.e., Benlate (benomyl), Derosal (carbendazim), Kasuran (kasugamycin), Healthied, Topsin-M (thiophanatemethyl), Dithane M-45 (mancozeb), Bayleton (triadimefon) and Ridomil (metalaxyl) were used in controlling bakanae disease of rice which gave significant reduction in disease incidence and increased seed germination and yield Dodan et al. (1994), Javaid and llyas (1995), Tateishi et al. (1998), Biswas and Das (2002), Kabir et al. (2006) and Bagga and Sharma (2006).

White tip nematode:

The present study carried out to evaluate some entries to white tip nematode disease. Results in Table (6) indicated that GZ 7769, HR 4856, Sakha 104, SK-101-Pa-3, Sakha 101 and SK-101-7-26 gave the highest infection. On the other hand, SP-7, SK-101-7-16, SK-101-7-17, SK-101-7-35, SK-101-7-37, GG-42-6-1, GG-42-1-2, GG-42-1-6 and SK-101-Pa-4 gave the lowest infection.

White tip disease of rice leaves caused by the rice leaf nematode, Aphelenchoides besseyi Christie (1942), is widespread and found nearly in all different world rice ecosystems, Ou (1985). Giudici et al. (2003) and Rajan and Lal (2006) reported that $A$. besseyi is a seed transmitted plant parasitic nematode that can dramatically affect rice growth and yield. Abdel Hadi et al. (2005) investigated A. besseyi damage, infection, dynamic symptoms and epidemic features in different locations. They found that the disease is widely spread all over Egypt governorates, causing remarkable yield reduction in the susceptible old rice cultivars Giza 171 and Reiho in addition to the new rice cultivars Giza 177, Sakha 102 and Sakha 103 with different levels of infection and yield losses in old cultivars, reaching $47 \%$ as recorded later by El-Shafey (2007), who studied also the effects of seed priming for $48 \mathrm{hr}$ with $\mathrm{NaCl}$ 
solutions at the concentrations of 25,35 and $50 \mathrm{~g} / \mathrm{L}$ and sulfur at $1.5,3$ and 5 $\mathrm{g} / \mathrm{L}$ on rice seeds.

Table (4): Reaction of rice races to leaf blast disease, Pyricularia grisea under greenhouse and field conditions.

\begin{tabular}{|c|c|c|c|c|c|c|c|c|c|c|c|}
\hline \multirow[b]{2}{*}{ No. } & \multirow{2}{*}{ Entries } & \multicolumn{8}{|c|}{ Greenhouse test } & \multicolumn{2}{|c|}{ Field Reaction } \\
\hline & & IG-1 & || $\mid \mathrm{B}-45$ & IC-9 & IC-13 & ID-5 & \begin{tabular}{|l|} 
ID-7 \\
\end{tabular} & $\mid$ IF-11 & IH & 2012 & 2013 \\
\hline 1 & Sakha 101 & $\mathrm{~S}$ & $\mathrm{R}$ & HS & $\mathrm{S}$ & $\mathrm{S}$ & $\mathrm{S}$ & HS & HS & $\mathrm{S}$ & HS \\
\hline 2 & SP- 70 & $\mathrm{R}$ & $\mathrm{R}$ & $\mathrm{R}$ & $\mathrm{R}$ & $\mathrm{R}$ & $\mathrm{R}$ & $\mathrm{R}$ & $\mathrm{R}$ & $\mathrm{R}$ & $\mathrm{R}$ \\
\hline 3 & IRAT 112 & $\mathrm{R}$ & $\mathrm{R}$ & $\mathrm{R}$ & $\mathrm{R}$ & $\mathrm{R}$ & $\mathrm{R}$ & $\mathrm{R}$ & $\mathrm{R}$ & $\mathrm{R}$ & $\mathrm{R}$ \\
\hline 4 & IR 65610-105-2-5 & $\mathrm{R}$ & $\mathrm{R}$ & $\mathrm{R}$ & $\mathrm{R}$ & $\mathrm{R}$ & $\mathrm{R}$ & $\mathrm{R}$ & $\mathrm{R}$ & $\mathrm{R}$ & $\mathrm{R}$ \\
\hline 5 & Sakha 104 & $\mathrm{R}$ & $\mathrm{S}$ & $\mathrm{R}$ & $\mathrm{R}$ & $\mathrm{R}$ & $\mathrm{R}$ & $\mathrm{R}$ & $\mathrm{R}$ & S & S \\
\hline 6 & HR 4856-1-1-1-1-2 & $\mathrm{R}$ & $\mathrm{R}$ & $\mathrm{S}$ & $\mathrm{R}$ & $\mathrm{R}$ & $\mathrm{R}$ & $S$ & $\mathrm{R}$ & $\mathrm{R}$ & $R$ \\
\hline 7 & GZ 7769-2-1-1-2 & $\mathrm{R}$ & $\mathrm{R}$ & $\mathrm{R}$ & $\mathrm{R}$ & $\mathrm{R}$ & $\mathrm{R}$ & $\mathrm{R}$ & $\mathrm{R}$ & $\mathrm{R}$ & $\mathrm{R}$ \\
\hline 8 & SK-101-7-16 & $\mathrm{R}$ & $\mathrm{R}$ & $\mathrm{R}$ & $\mathrm{R}$ & $\mathrm{R}$ & $\mathrm{R}$ & $\mathrm{R}$ & $\mathrm{R}$ & $\mathrm{R}$ & $\mathrm{R}$ \\
\hline 9 & SK-101-7-17 & $\mathrm{R}$ & $\mathrm{R}$ & $\mathrm{R}$ & $\mathrm{R}$ & $\mathrm{R}$ & $\mathrm{R}$ & $\mathrm{R}$ & $\mathrm{R}$ & $\mathrm{R}$ & $\mathrm{R}$ \\
\hline 10 & SK-101-7-25 & $\mathrm{R}$ & $\mathrm{R}$ & $\mathrm{R}$ & $\mathrm{R}$ & $\mathrm{R}$ & $\mathrm{R}$ & $\mathrm{R}$ & $\mathrm{R}$ & $\mathrm{R}$ & $\mathrm{R}$ \\
\hline 11 & SK-101-7-26 & $\mathrm{R}$ & $\mathrm{R}$ & $\mathrm{R}$ & $\mathrm{R}$ & $\mathrm{R}$ & $\mathrm{R}$ & $\mathrm{R}$ & $\mathrm{R}$ & $\mathrm{R}$ & $\mathrm{R}$ \\
\hline 12 & SK-101-7-35 & $\mathrm{R}$ & $\mathrm{R}$ & $\mathrm{R}$ & $\mathrm{R}$ & $\mathrm{R}$ & $\mathrm{R}$ & $\mathrm{R}$ & $\mathrm{R}$ & $\mathrm{R}$ & $\mathrm{R}$ \\
\hline 13 & SK-101-7-37 & $\mathrm{R}$ & $\mathrm{R}$ & $\mathrm{R}$ & $\mathrm{R}$ & $\mathrm{R}$ & $\mathrm{R}$ & $\mathrm{R}$ & $\mathrm{R}$ & $\mathrm{R}$ & $\mathrm{R}$ \\
\hline 14 & GG-46-6-1 & $\mathrm{R}$ & $\mathrm{R}$ & $\mathrm{R}$ & $\mathrm{R}$ & $\mathrm{R}$ & $\mathrm{R}$ & $\mathrm{R}$ & $\mathrm{R}$ & $\mathrm{R}$ & $\mathrm{R}$ \\
\hline 15 & GG-42-1-2 & S & $\mathrm{R}$ & S & $\mathrm{R}$ & $\mathrm{R}$ & $\mathrm{R}$ & MR & $\mathrm{R}$ & S & S \\
\hline 16 & GG-42-2-6 & $\mathrm{R}$ & $S$ & $\mathrm{R}$ & $\mathrm{R}$ & $\mathrm{R}$ & $\mathrm{R}$ & $\mathrm{R}$ & $\mathrm{R}$ & $\mathrm{R}$ & $\mathrm{R}$ \\
\hline 17 & SK-101-Pa-1 & $\mathrm{R}$ & $\mathrm{R}$ & $\mathrm{R}$ & $\mathrm{R}$ & $\mathrm{R}$ & $\mathrm{R}$ & $\mathrm{R}$ & $\mathrm{R}$ & $\mathrm{R}$ & $\mathrm{R}$ \\
\hline 18 & SK-101-Pa-3 & $\mathrm{R}$ & $\mathrm{R}$ & $\mathrm{R}$ & $\mathrm{R}$ & $\mathrm{R}$ & $\mathrm{R}$ & $\mathrm{R}$ & $\mathrm{R}$ & $\mathrm{R}$ & $\mathrm{R}$ \\
\hline 19 & SK-101-Pa-4 & $\mathrm{R}$ & $\mathrm{R}$ & $\mathrm{R}$ & $\mathrm{R}$ & $\mathrm{R}$ & $\mathrm{R}$ & $\mathrm{R}$ & $\mathrm{R}$ & $\mathrm{R}$ & $\mathrm{R}$ \\
\hline 20 & SK-101-Pa-6 & $S$ & $\mathrm{R}$ & $S$ & $S$ & MR & $S$ & $\mathrm{~S}$ & $S$ & $S$ & $\mathrm{HS}$ \\
\hline
\end{tabular}

Table (5) Reaction of 20 rice genotypes to eight different isolates of Pyricularia grisea under greenhouse condition.

\begin{tabular}{|l|c|c|c|c|c|c|c|c|}
\hline \multirow{2}{*}{ Reaction } & \multicolumn{6}{|c|}{ Number of entries as infected by blast races } \\
\cline { 2 - 9 } & IG-1 & IB-45 & IC-9 & IC-13 & ID-5 & ID-7 & IF-11 & IH \\
\hline Resistant ( R ) & 17 & 18 & 16 & 18 & 18 & 18 & 16 & 18 \\
\hline Moderately resistant (MR) & - & - & - & - & 1 & - & 1 & - \\
\hline Susceptible ( S) & 3 & 2 & 3 & 2 & 1 & 2 & 2 & 1 \\
\hline Highly susceptible (HS) & - & - & 1 & - & - & - & 1 & 1 \\
\hline
\end{tabular}


Hammoud S. A. A. and W. S. Gabr

6 
J. Plant Prot. and Path., Mansoura Univ., Vol. 5 (9), September, 2014

7 
Table (8): Reaction of rice genotypes to bakanae disease (Fusarium moniliforme) under lab. conditions during 2012 season

\begin{tabular}{|c|c|c|c|c|c|}
\hline \multirow[b]{2}{*}{ No. } & \multirow[b]{2}{*}{ Entry } & \multicolumn{2}{|c|}{ Bakanae \% } & \multicolumn{2}{|c|}{$\begin{array}{l}\text { Bakanae \% under } \\
\text { inoculated }\end{array}$} \\
\hline & & Non-inoculated & inoculated & $\begin{array}{l}\text { Treated with } \\
\text { Vitavax } 2 \mathrm{~g} / \mathrm{l}\end{array}$ & $\begin{array}{l}\text { Treated with } \\
\text { sodium } \\
\text { chloride } 50 / 1\end{array}$ \\
\hline 1 & Sakha 101 & 1.667 & 89.33 & 4.67 & 29.33 \\
\hline 2 & SP- 70 & 0.133 & 62.67 & 2.33 & 16.76 \\
\hline 3 & IRAT 112 & 0.133 & 52.33 & 1.67 & 14.33 \\
\hline 4 & IR 6560 & 0.133 & 64.33 & 2.33 & 26.76 \\
\hline 5 & Sakha 104 & 0.767 & 25.67 & 1.00 & 13.33 \\
\hline 6 & HR 4856 & 0.133 & 79.33 & 3.33 & 27.33 \\
\hline 7 & GZ 7769 & 0.133 & 60.33 & 2.67 & 22.00 \\
\hline 8 & SK-101-7-16 & 1.133 & 74.33 & 3.67 & 23.33 \\
\hline 9 & SK-101-7-17 & 0.167 & 62.33 & 4.00 & 23.67 \\
\hline 10 & SK-101-7-25 & 3.000 & 79.00 & 1.00 & 21.67 \\
\hline 11 & SK-101-7-26 & 1.333 & 81.00 & 3.00 & 24.33 \\
\hline 12 & SK-101-7-35 & 0.133 & 73.33 & 2.00 & 27.67 \\
\hline 13 & SK-101-7-37 & 0.433 & 80.00 & 1.67 & 31.00 \\
\hline 14 & GG-46-6-1 & 0.133 & 83.67 & 1.67 & 28.33 \\
\hline 15 & GG-42-1-2 & 0.133 & 71.33 & 2.00 & 22.00 \\
\hline 16 & GG-42-2-6 & 0.133 & 90.00 & 3.33 & 25.67 \\
\hline 17 & SK-101-Pa-1 & 0.767 & 81.00 & 4.00 & 26.67 \\
\hline 18 & SK-101-Pa-3 & 0.133 & 77.67 & 2.67 & 26.00 \\
\hline 19 & SK-101-Pa-4 & 0.133 & 87.33 & 3.00 & 26.00 \\
\hline 20 & SK-101-Pa-6 & 2.667 & 78.00 & 2.33 & 23.00 \\
\hline \multicolumn{2}{|c|}{ L.S.D. $5 \%$} & 1.0070 & 10.964 & 2.018 & 4.785 \\
\hline
\end{tabular}

Table (9): Effect of inoculation by bakanae disease (Fusarium moniliforme) on some rice genotypes under lab. conditions during 2012 season.

\begin{tabular}{|c|l|c|c|c|c|c|c|c|c|}
\hline \multirow{2}{*}{ No. } & \multicolumn{1}{|c|}{ Entry } & \multicolumn{4}{|c|}{ Healthy plant } & \multicolumn{3}{c|}{ Inoculated plant } \\
\cline { 3 - 9 } & & $\begin{array}{c}\text { Shoot } \\
\text { length }\end{array}$ & $\begin{array}{c}\text { Root } \\
\text { length }\end{array}$ & $\begin{array}{c}\text { Fresh } \\
\text { weight }\end{array}$ & $\begin{array}{c}\text { Dry } \\
\text { weight }\end{array}$ & $\begin{array}{c}\text { Shoot } \\
\text { length }\end{array}$ & $\begin{array}{c}\text { Root } \\
\text { length }\end{array}$ & $\begin{array}{c}\text { Fresh } \\
\text { weight }\end{array}$ & $\begin{array}{c}\text { Dry } \\
\text { weight }\end{array}$ \\
\hline 1 & Sakha 101 & 6.500 & 10.200 & 3.700 & 1.200 & 9.933 & 15.200 & 3.250 & 0.900 \\
2 & SP-70 & 5.567 & 8.900 & 3.200 & 1.500 & 8.700 & 13.433 & 3.600 & 1.200 \\
3 & IRAT 112 & 5.200 & 9.200 & 3.500 & 1.333 & 7.500 & 14.233 & 3.233 & 1.300 \\
4 & IR 6560 & 6.800 & 10.133 & 4.200 & 1.400 & 8.200 & 13.333 & 3.400 & 1.200 \\
5 & Sakha 104 & 5.833 & 7.500 & 3.900 & 1.233 & 7.330 & 12.100 & 3.562 & 1.300 \\
6 & HR 4856 & 5.500 & 8.933 & 4.033 & 1.417 & 7.900 & 14.93 & 3.400 & 1.000 \\
7 & GZ 7769 & 6.567 & 10.100 & 4.700 & 1.567 & 9.100 & 15.43 & 3.833 & 1.200 \\
8 & SK-101-7-16 & 6.200 & 10.133 & 3.967 & 1.417 & 9.533 & 13.47 & 3.433 & 1.067 \\
9 & SK-101-7-17 & 5.733 & 10.367 & 4.500 & 1.533 & 8.133 & 15.37 & 3.667 & 1.133 \\
10 & SK-101-7-25 & 5.933 & 9.200 & 4.167 & 1.483 & 8.467 & 13.20 & 3.200 & 0.983 \\
11 & SK-101-7-26 & 5.800 & 7.933 & 4.267 & 1.343 & 8.633 & 15.60 & 3.567 & 1.090 \\
12 & SK-101-7-35 & 5.233 & 7.633 & 3.800 & 1.150 & 7.267 & 12.30 & 3.033 & 0.967 \\
13 & SK-101-7-37 & 5.833 & 10.167 & 4.133 & 1.350 & 8.667 & 14.17 & 3.400 & 1.133 \\
14 & GG-46-6-1 & 6.033 & 10.200 & 4.600 & 1.500 & 9.167 & 15.87 & 3.967 & 1.250 \\
15 & GG-42-1-2 & 5.367 & 8.900 & 3.767 & 1.225 & 7.800 & 14.23 & 3.100 & 0.965 \\
16 & GG-42-2-6 & 6.033 & 9.233 & 4.300 & 1.533 & 9.567 & 13.57 & 3.767 & 1.200 \\
17 & SK-101-Pa-1 & 5.733 & 8.450 & 4.167 & 1.300 & 8.567 & 12.57 & 3.167 & 0.983 \\
18 & SK-101-Pa-3 & 6.033 & 10.100 & 4.200 & 1.317 & 8.933 & 14.43 & 3.467 & 1.100 \\
19 & SK-101-Pa-4 & 5.800 & 9.633 & 3.767 & 1.333 & 8.733 & 13.30 & 3.233 & 1.000 \\
20 & SK-101-Pa-6 & 6.000 & 9.400 & 4.200 & 1.417 & 9.133 & 13.07 & 3.567 & 1.133 \\
\hline & L.S.D. 5\% $\%$ & 0.4280 & 0.8566 & 0.4065 & 0.2262 & 0.7664 & 2.448 & 0.3816 & 0.1544 \\
\hline
\end{tabular}




\section{REFERENCES}

Abdel Hadi, M. A., E. I. El-Shafeey, M. S. Tadros and M. H. Soliman (2005). Occurrence distribution and epidimics of white tip nematode (Aphelenchoides besseyi) on rice plants in Egypt. J. Agric. Sci. Mansoura Univ., 30(2):1169-1182.

Atkins J.G., A.L. Robert, C.R. Adair, K. Goto K., T. Kozaka, R. Yanagida, Y. Yamada and S. Matsumoto (1967). An international set of rice varieties for differentiating races of Pyricularia oryzae. Phytopathology, 57: 298301.

Aurangzeb, M.; A. Shafqat; I. Bashir and M.A. Gill (2003). Physiological studies on Fusarium moniliforme Sheld, the causal organism of bakanae disease of rice. Mycopath., 1 (1): 49-52.

Aurangzeb, M.; J. Ahmed and M.B. Ilyas (1998). Chemical control of bakanae disease of rice caused by Fusarium moniliforme. Pakistan Journal of Phytopathology, 10 (1): 14-17.

Bagga, P.S. and V.K. Sharma (2006). Evaluation of fungicides as seedling treatment for controlling bakanae/foot-rot (Fusarium moniliforme) disease in Basmati rice. Indian Phytopathology, 59 (3): 305-308.

Biswas, S. and S.N. Das (2002). Efficacy of fungicides for the control of bakanae disease of rice. Annals-of-Plant-Protection-Sciences, 10 (2): 288-290.

Biswas, S. and S.N. Das (2003). Fungicidal spraying for control of bakanae disease of rice in field. Journal of Mycopathological Research, 40 (2): 211-212.

Bonman J. M., B. A. Estrada, C. K. Kim, C. K. Ra and E. J. Lee (1991). Assessment of blast disease and yield losses in susceptible and partial resistant rice cultivars in two irrigated and low land environments. Plant Dis., 75 : $462-466$.

Chen, Z.Q. (1989). Investigations on tile mechanism of resistance to rice blast disease. Journal of South China Agricultural University 10, 82-91.

Dodan, D.S., S. Ram and S. Sunder (1994). Survival of Fusarium moniliforme in infected rice grains and its chemical control. Indian Journal of Mycology and Plant Pathology, 24(2): 135-138.

EL-Shafey, R.A.S. (2007). Biological and ecological studies on white tip nematode in rice with special reference to its control. Ph.D. Thesis, Fac. Agric., Kafr EL-Sheikh University

Evenson, R.E. (1998). The economic value of genetic improvement in rice. In: Dowling NG, Greenfield SM, Fischer KS (eds). Sustainability of Rice in the Global Food System. Manila: International Rice Research Institute. 303-320 pp.

FAO., (2012). The state of food and agriculture 2011-12. Agricultural biotechnology: Meeting the needs of the poor? FAO Agriculture Series No. 43. Food and Agriculture Organization of the United Nations, Rome.

Gabr, W.S. (2004). Studies on rice blast disease in Egypt. M.Sc. Thesis, Fac. Agric., Tanta Univ., Egypt. 
Ghazanfar, M.U., A. Habib, S. T. Sahi (2009). Screening of rice germ plasm against Pyricularia oryza the cause of rice Blast disease. Pak. J. Phytopath., 21: 41-44.

Giudici, M.L., B.Villa, A.M. Collegarin and L. Tamborini (2003). white tip disease in Italian rice. Proceeding of the 3rd International Rice Conference, 10-13 March, Punta de L"Este, Uruguay.

Griffing J.B. (1956). Concept of general and specific combining ability in relation to diallel crossing systems. Australian Journal of Biological Sciences 9: 463-493.

Hansen, H.C. (1926). A simple method of obtained single spore culture. Science, 64: 384-1959.

IRRI (International Rice Research Institute) (1996). Standard Evaluation System for Rice (IRRI) P.O. Box 933. 1099 Manila Philippines.

Javaid, M.S. and M.B. Ilyas (1995). Effect of various fungicides on the control of bakanae disease of rice and rice yield. Pakistan Journal of Phytopathology, 7(1): 53-55.

Jeff, O. (2001). New threat: Foolish seedling disease pops up in California. Rice J., 104: 20-21.

Kabir, M.H.; S.M.A. Islam; N. Sultana; M.A.K. Azad and G.A. Fakir (2006). Effect of seed cleaning, washing and treating with Vitavax on incidence and severity of Boro rice diseases. International Journal of Sustainable Agricultural Technology, 2(2): 27-31.

Khan, J.A.; F.F. Jamil and M.A. Gill (2000). Screening of rice varieties/lines against bakanae and bacterial leaf blight (BLB). Pakistan Journal of Phytopathology, 12(1): 6-11.

Kiyosawa S. (1974). Studies on genetic breeding of blast resistance in rice, Misc. Publ. Bull. Natl. Agric. Sci. D1, 1-58 (in Japanese, English summary).

Kozaka, T. (1965). Control of rice blast by cultural practices in Japan. The Rice Blast Disease. Proceedings of a symposium at The International Rice Research Institute. Baltimore:Johns Hopkins University Press.

Kumar, I. (1984). A rapid method for identifying different dwarf genes in rice. Rice Genet. Newsl., 1:134-135.

$\mathrm{Li}$, D.J. and K. Luo (1997). Study of the relationship between the occurrence of bakanae disease in Hybrid rice and the application of gibberellin to seed reproduction. J. Hunan Agric. Univ., 23: 47-49.

Li, X.M.; L.Y. Ma; X.D. Zhu and C.D. Yang (2005). Study on sensitivity of different dwarf materials/lines to gibberellic acid and PP333. J. Fujian Agric. Forest. Univ. (Natural Science Edition), 34: 5-10.

Mew, T.W. (1991). Disease management in rice. CRC Handbook of Pest Management. 2nd Ed.Vol. III. D. Pimentel and A. A. Hanson, eds. CRC Press, Boca Raton. 279-299 pp.

Nelson, P.E., T.A. Toussoum and W.F. Marasas (1983). Fusarium spp. an illustrated manual for identification. The state University Press, Penn, USA, pp. 203.

Ou, S.H. (1985). Rice Diseases (2nd edn). CMI, Kew, UK. 
Patel, D.P., A. Das, G.C. Munda, P.K. Ghosh, J.S. Bordoloi and M. Kumar (2010). Evaluation of yield and physiological attributes of high-yielding rice varieties under aerobic and flood-irrigated management practices in mid-hills ecosystem. Agric. Water Manage., 97: 1269-1276.

Rood, M.A. (2004). Bakanae in field yield loss. Rice J., 15: 8-10.

Roumen, E.C., J.M. Bonman and J.E. Parlevliet (1993). Leaf age related partial resistance to $P$. oryzae in tropical lowland rice cultivars as measured by the number of sporulating lesions. Phytopathology, 82: 1414-1417.

RRTC (2012). Rice Research and Training Center. Annual Rice National Campaign Report of rice program, Agric. Res. Center, Ministry of Agriculture and Land Reclamation.

Sanghera, G.S., A.M. Husaini, A. Anwer and S.C. Kashyap SC (2011) Evaluation of some rice genotypes for cold tolerance and leaf blast disease under temperate Kashmir conditions. Journal of Hill Agriculture 2(1): 28-32.

Sehly, M.R., Z.H. Osman, and E.A. Salem (2002). Rice diseases .In: Rice in Egypt pp 301.

Summerell, B.A; B. Salleh and J.F. Lislie (2003). A utilitarian approach to Fusarium identification. Plant Dis., 87 (2): 117-128.

Tasleem-uz, Z.K.; M.A. Gill; K.M. Bajwa and M.G. Khan (1999). Inheritance studies for bakanae disease of rice. Pakistan Journal of Phytopathology, 11(2): 181-182.

Tateishi, H.; T. Saishoji; T. Suzuki and T. Chida (1998). Antifungal properties of the seed disinfectant ipconazole and its protection against "Bakanae" and other diseases of rice. Annals of the Phytopathological Society of Japan, 64(5): 443-450.

Townsend, G.R. and J.W. Huberger (1943). Methods of estimating losses caused by diseases in fungicide experiments. Plant Dis.Reptr.27 (7): 340-343.

Veillet, S.M., C. Filippi and A. Gallais (1996). Combined genetic analysis of partial blast resistance in an upland rice population and recurrent selection for line and hybrid values. Theor, Appi. Genet., 92: 644-653.

Wang, G.L., D.J. Mackill, J.M. Bonman, S.R. McCouch, C.M. Champoux and R.J. Nelson (1994). RFLP mapping of genes conferring complete and partial resistance to blast in a durably resistant rice cultivar. Genetics 136:421-434.

Yamada, M., S. Kiyosawa, T. Yamaguchi, T. Hirano, T. Kubayashi, K. Kushibuchi and S. Watanabe (1976). Proposal of a new method for differentiating races of P. oryzae Cav. in japan. Ann. Phytopath. Soc. japan., 42: 216-219. 
سلوك بعض التراكيب الوراثيـة من الأرز ومدي تأثرهـا بالإصـابة ببعض الأمراض

تحت ظروف بيئية مختلفة

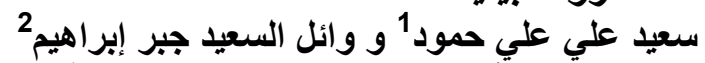

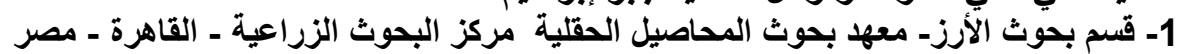

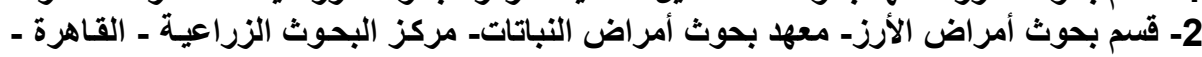

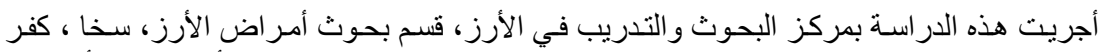

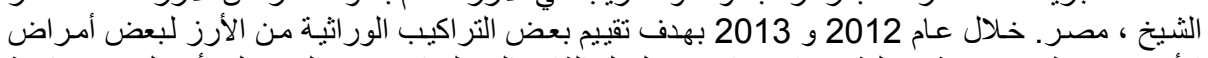

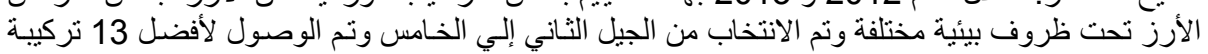

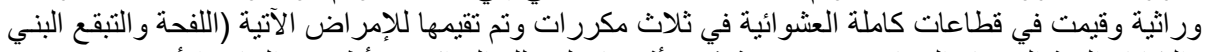

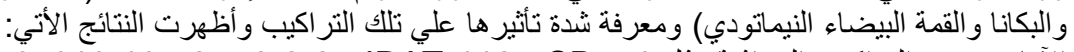

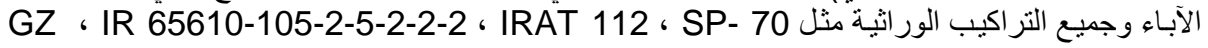

SK- ، SK-101-7-26 ، SK-101-7-25 ، SK-101-7-17 ، SK-101-7-16 77769-2-1-1-2

SK-101- ، SK-101-Pa-3 ، SK-101-Pa-1، GG-46-6-1 ، SK-101-7-37 ،101- 7-35

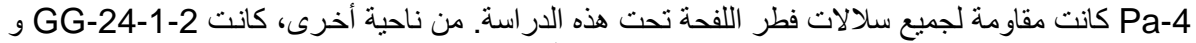

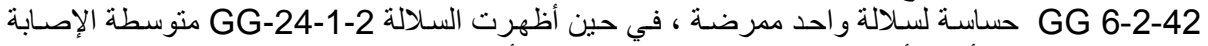

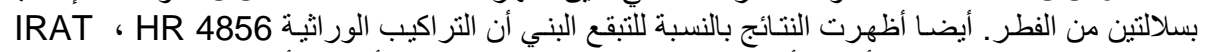

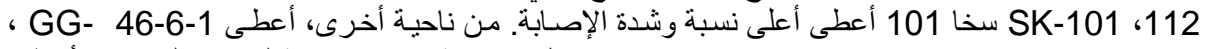
القل في نسبة وشدة الإصابة لمرض البكانا ، و أعطي

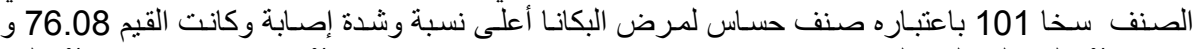

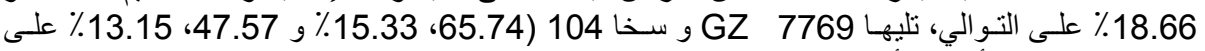

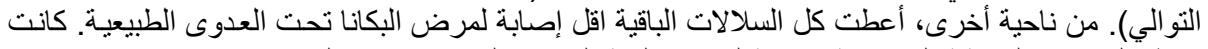

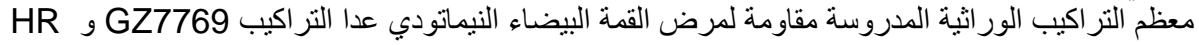

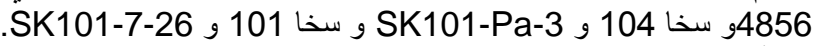

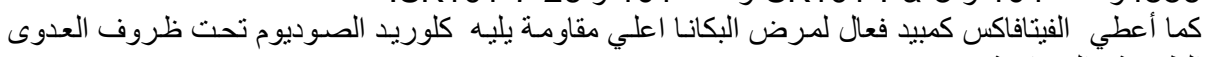

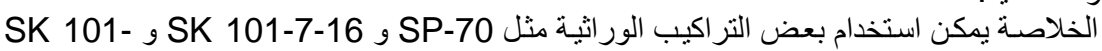
, GG 42-1-6, GG 42-1-2, GG-46-6-1 , SK 101-7-37, SK 101-7-35 , 7-17 كمدر لمقاومة معظم أمر اض الأرز في برنامج التربية أو مبانرة كصنف و انتخاب أفضلها لافعة للتسجيل خاصة التر اكيب الور اثية ذات المقاومة المتعددة. 
J. Plant Prot. and Path., Mansoura Univ., Vol. 5 (9), September, 2014 

J. Plant Prot. and Path., Mansoura Univ., Vol. 5 (9): 871 - 890, 2014

Table (3): Mean performance of twenty rice genotypes and their combined data for some agronomic traits at the two seasons of 2012 and 2013.

\begin{tabular}{|c|c|c|c|c|c|c|c|c|c|c|c|c|c|}
\hline \multirow{2}{*}{ No. } & \multirow{2}{*}{ Genotype } & \multicolumn{3}{|c|}{ Plant height (cm) } & \multicolumn{3}{|c|}{ Flag leaf area $\left(\mathrm{cm}^{2}\right)$} & \multicolumn{3}{|c|}{ Duration (Day) } & \multicolumn{3}{|c|}{ Panicle number/Plant } \\
\hline & & $Y_{1}{ }^{*}$ & $\mathbf{Y}_{2}{ }^{*}$ & Comb. * & $Y_{1}^{*}$ & $\mathbf{Y}_{2}{ }^{*}$ & Comb. * & $Y_{1}{ }^{*}$ & $\mathbf{Y}_{2}{ }^{*}$ & Comb. * & $Y_{1}{ }^{*}$ & $\mathrm{Y}_{2}{ }^{*}$ & Comb. * \\
\hline 1 & Sakha 101 & 84.60 & 86.92 & 85.76 & 32.61 & 33.17 & 31.49 & 145.00 & 146.00 & 144.0 & 24.00 & 23.00 & 25.00 \\
\hline 2 & SP-7 & 91.50 & 90.14 & 92.31 & 2.13 & 31.01 & 33.47 & 133.17 & 137.15 & 134.10 & 6.17 & 25.11 & 27.21 \\
\hline 3 & IRAT 112 & 109.0 & 108.0 & 110.0 & .17 & 32.11 & 36.77 & 129.00 & 130.0 & 131.00 & 3.15 & 4.15 & 22.97 \\
\hline 4 & & 101.0 & 99.00 & 100.0 & & & 53.00 & 131.00 & 132.00 & & & & 16.57 \\
\hline 5 & Sakha 104 & 104 & 105 & 106.0 & & & & 135 & & & & & 3.57 \\
\hline 6 & & $7<$ & 7 & 76 & & & & 74 & & & & & .01 \\
\hline 7 & & 95 & 9 & .11 & & & 28.15 & 92 & & & & & .22 \\
\hline 8 & & 92.3 & 94. & 93 & & & 28.07 & 139 & & & & & .00 \\
\hline 9 & & 89.33 & 87.33 & 88.33 & & & 30.37 & 136 & 135.7 & .02 & 2.67 & & 22.17 \\
\hline 10 & & 93.00 & 95.00 & 94.00 & & & 33.21 & 128 & 127.7 & 85 & 00 & & 24.34 \\
\hline 11 & SK-1 & 99.00 & 103.67 & 101.34 & 31. & 28 & 29.66 & 123 & & 17 & & & 21.84 \\
\hline 12 & & 91.67 & 91.00 & 91.34 & 28. & 28 & 28.69 & 129 & & & & & 24.17 \\
\hline 13 & & 91.67 & 93.67 & 92.67 & & & 34.01 & 129 & & & & & 24.00 \\
\hline 14 & & 102.00 & 105.67 & 103.84 & & & & & & & & & 19.34 \\
\hline 15 & & & & & & & & & & & & & .84 \\
\hline & & & & & & & & & & & & & .00 \\
\hline & & & & & & & & & & & & & 23.00 \\
\hline 18 & & 94.6 & & & & & 36.37 & 124 & & & & & 32. 50 \\
\hline 19 & SK-1 & 96.33 & 1.00 & 98.67 & 39.86 & 39 & 39.69 & 126 & 125.0 & & & & 19.00 \\
\hline 20 & SK- & 97.67 & 101.00 & 99.34 & 35.22 & & 34.47 & 130.67 & 130.3 & 130 & 20.00 & & 20.00 \\
\hline \multirow{2}{*}{\multicolumn{2}{|c|}{ Range }} & 85.33 & 86.33 & 85.82 & 28.49 & 27.51 & 28.07 & 120.33 & 119.30 & 119.82 & 17.33 & 19.33 & 19.00 \\
\hline & & 102.00 & 105.67 & 103.84 & 43.95 & 19 & 44.07 & 145 & 145.00 & 145.00 & 26.67 & 35.67 & 26.17 \\
\hline \multirow{2}{*}{\multicolumn{2}{|c|}{$\begin{array}{r}\text { L.S.D } 05 \% \\
01 \% \\
\end{array}$}} & 3.03 & 2.195 & 2.610 & 2.706 & 2.484 & 2.60 & & 1.98 & 1.76 & 1.704 & 1.292 & 1.49 \\
\hline & & 5.11 & 3.950 & 4.010 & 3.970 & 3.870 & 3.94 & 2.520 & 3.12 & 2.04 & 3.100 & 2.930 & 2.99 \\
\hline
\end{tabular}


Hammoud S. A. A. and W. S. Gabr

Table (3): continued.

\begin{tabular}{|c|c|c|c|c|c|c|c|c|c|c|c|c|c|}
\hline \multirow[t]{2}{*}{ No. } & \multirow[t]{2}{*}{ Genotype } & \multicolumn{3}{|c|}{ Panicle length (cm) } & \multicolumn{3}{|c|}{$\begin{array}{c}\text { No. of filled } \\
\text { grains/Panicle }\end{array}$} & \multicolumn{3}{|c|}{1000 grain weight $(\mathrm{g})$} & \multicolumn{3}{|c|}{ Hulling \% } \\
\hline & & $Y_{1}{ }^{*}$ & $\mathrm{Y}_{2}{ }^{*}$ & Comb. * & $\mathrm{Y}_{1}^{*}$ & $\mathrm{Y}_{2}{ }^{*}$ & Comb. * & $\mathbf{Y}_{1}{ }^{*}$ & $\mathrm{Y}_{2}{ }^{*}$ & Comb. * & $\mathbf{Y}_{1}{ }^{*}$ & $\mathbf{Y}_{2}{ }^{*}$ & Comb. * \\
\hline 1 & Sakha 101 & 22.10 & 24.11 & 23.77 & 145.16 & 150.16 & 149.36 & 27.15 & 28.15 & 28.17 & 80.15 & 81.15 & 80.31 \\
\hline 2 & SP-7 & 24.15 & 23.55 & 24.79 & 159.71 & 158.95 & 158.15 & & & & 81.44 & 82.15 & 81.44 \\
\hline 3 & IRAT 112 & 23.15 & 24.01 & 23.15 & 133.26 & 135.11 & 134.77 & 25.15 & 25.72 & 25.01 & 75.17 & 76.11 & 75.24 \\
\hline 4 & IR 6560 & 27.11 & 27.51 & 27.22 & 250.16 & 226.72 & 255.14 & & & & 72.15 & & 72.35 \\
\hline 5 & Sakha 104 & 21.41 & 20.15 & & & & 134 & & & & & & .15 \\
\hline 6 & & & & & & & & & & & & & \\
\hline 7 & & & & & 110 & & 114 & & & & & & \\
\hline 8 & SK- & 25.3 & & 6 & & & 132 & & & & & & \\
\hline 9 & & 24.09 & & 52 & & & 137 & & & & & & \\
\hline 10 & 01-7-25 & 22.07 & 24.03 & 23.05 & 140.0 & 15 & 145 & 28 & & & & & \\
\hline 11 & $01-7-26$ & 27.33 & 21.61 & 24. & 14 & 12 & 136 & & & & & & 2.11 \\
\hline 12 & $01-7-35$ & 22.33 & 23.89 & 23. & 14 & 15 & 152 & & & & 82. & & 14 \\
\hline 13 & SK-101-7-37 & 23.20 & 22.8 & & 15 & & 152.32 & & & & & & 1.11 \\
\hline 14 & & 25.87 & 25. & & 238 & & 227.0 & & & & & & 4.78 \\
\hline 15 & & 22. & & & & & 131 & & & & & & 21 \\
\hline 16 & & & & & & & & & & & & & \\
\hline 17 & $a-1$ & 21. & & 22.47 & 142.0 & & 143 & & & & & & \\
\hline 18 & a-3 & 26.50 & 22. & 24.41 & 142.0 & & 142 & & & & 82.263 & & 56 \\
\hline 19 & Рa-4 & 22.87 & 21.65 & 22.26 & 137 & $12 \varepsilon$ & 133 & & & & & & .18 \\
\hline 20 & $1-r a-b$ & 21.47 & 19.46 & 20.47 & 118.3 & 116.0 & 117.15 & 29.63 & 29.14 & 29.39 & 83.240 & 83.86 & 83.55 \\
\hline \multirow{2}{*}{\multicolumn{2}{|c|}{ Range }} & 21.47 & 19.46 & 20.47 & 118.30 & 116.00 & 117.15 & 24.20 & 24.09 & 24.33 & 63.62 & 73.52 & 69.07 \\
\hline & & 27.33 & 27.27 & 26.84 & 247.30 & 216.00 & 231.15 & 29.83 & 31.42 & 30.07 & 83.87 & 84.09 & 83.55 \\
\hline \multirow{2}{*}{\multicolumn{2}{|c|}{$\begin{array}{r}\text { L.S.D } 05 \% \\
01 \% \\
\end{array}$}} & 1.514 & 0.9296 & 1.222 & 12.45 & 12.65 & 12.55 & 0.7325 & 1.452 & & 1.0395 & & 1.716 \\
\hline & & 2.460 & 1.5400 & 2.010 & 13.15 & 13.02 & 13.30 & 1.1400 & 1.960 & 1.660 & 2.1100 & 3.450 & 1.990 \\
\hline
\end{tabular}


J. Plant Prot. and Path., Mansoura Univ., Vol. 5 (9), September, 2014

Table (3): continued.

\begin{tabular}{|c|c|c|c|c|c|c|c|}
\hline \multirow{2}{*}{ No. } & \multirow{2}{*}{ Genotype } & \multicolumn{3}{|c|}{ Milling \% } & \multicolumn{3}{|c|}{ Grain yield (T/ha) } \\
\hline & & $Y_{1}{ }^{*}$ & $\mathbf{Y}_{2}{ }^{*}$ & Comb. * & $Y_{1}{ }^{*}$ & $\mathrm{Y}_{2}{ }^{*}$ & Comb. \\
\hline 1 & Sakha 101 & 70.11 & 69.51 & 69.79 & 11.61 & 10.95 & 11.02 \\
\hline 2 & SP-7 & 71.15 & 72.20 & 70.38 & 12.01 & 11.96 & 11.85 \\
\hline 3 & IRAT 112 & 60.11 & 60.17 & 55.70 & 8.51 & 8.81 & 8.97 \\
\hline 4 & IR 6560 & 52.55 & 55.46 & 50.71 & 7.45 & 8.01 & 7.55 \\
\hline 5 & Sakha 104 & 70.15 & 70.00 & 70.17 & 10.10 & 10.20 & 10.55 \\
\hline 6 & HR 4856 & 52.55 & 53.54 & 51.25 & 6.60 & 6.50 & 6.70 \\
\hline 7 & GZ 7769 & 71.05 & 70.00 & 70.17 & 10.00 & 9.30 & 9.50 \\
\hline 8 & SK-101-7-16 & 69.81 & 71.43 & 70.62 & 10.10 & 10.31 & 10.21 \\
\hline 9 & SK-101-7-17 & 68.95 & 67.36 & 68.16 & 10.55 & 10.36 & 10.40 \\
\hline 10 & SK-101-7-25 & 67.46 & 69.01 & 63.24 & 11.28 & 10.95 & 11.12 \\
\hline 11 & SK-101-7-26 & 70.80 & 69.01 & 69.91 & 10.36 & 9.80 & 10.09 \\
\hline 12 & SK-101-7-35 & 73.81 & 71.95 & 72.88 & 11.30 & 11.09 & 11.20 \\
\hline 13 & SK-101-7-37 & 70.62 & 70.36 & 70.49 & 10.79 & 10.73 & 10.76 \\
\hline 14 & GG-46-6-1 & 66.51 & 63.12 & 64.82 & 9.98 & 10.70 & 10.34 \\
\hline 15 & GG-42-1-2 & 66.74 & 68.21 & 67.48 & 10.91 & 10.79 & 10.86 \\
\hline 16 & GG-42-2-6 & 65.32 & 67.12 & 66.22 & 10.53 & 10.67 & 10.60 \\
\hline 17 & SK-101-Pa-1 & 72.34 & 72.84 & 72.59 & 10.88 & 10.66 & 10.78 \\
\hline 18 & SK-101-Pa-3 & 70.30 & 73.30 & 71.80 & 10.91 & 10.44 & 10.69 \\
\hline 19 & SK-101-Pa-4 & 71.42 & 72.24 & 71.83 & 10.27 & 9.97 & 10.12 \\
\hline 20 & SK-101-Pa-6 & 73.12 & 73.06 & 73.09 & 10.46 & 10.17 & 10.39 \\
\hline \multicolumn{2}{|c|}{ Range } & 65.22 & 63.12 & 64.82 & 9.98 & 9.80 & 10.09 \\
\hline \multirow{3}{*}{\multicolumn{2}{|c|}{$\begin{array}{c}\text { L.S.D } 05 \% \\
01 \% \\
\end{array}$}} & 13.01 & 13.00 & 13.09 & 12.14 & 11.00 & 11.90 \\
\hline & & 1.262 & 1.463 & 1.363 & 0.6568 & 0.6830 & 0.669 \\
\hline & & 1.870 & 2.010 & 2.660 & 1.2300 & 1.1400 & 1.220 \\
\hline
\end{tabular}


Hammoud S. A. A. and W. S. Gabr

Table (6): Mean performance of some rice genotypes and their combined data as affected by some rice diseases at the two seasons 2012 and 2013

\begin{tabular}{|c|c|c|c|c|c|c|c|c|c|c|}
\hline \multirow{2}{*}{ No. } & \multirow{2}{*}{ Genotype } & \multicolumn{3}{|c|}{ Brown spot \% } & \multicolumn{3}{|c|}{ Brown spot severity \% } & \multicolumn{3}{|c|}{ White tip nematode \% } \\
\hline & & $Y_{1}{ }^{*}$ & $Y_{2}{ }^{*}$ & Comb. * & $\mathrm{Y}_{1}{ }^{*}$ & $\mathrm{Y}_{2}{ }^{*}$ & Comb. * & $\mathrm{Y}_{1}{ }^{*}$ & $Y_{2}{ }^{*}$ & Comb. * \\
\hline 1 & Sakha 101 & 44.67 & 45.50 & 45.08 & 215.50 & 220.00 & 217.75 & 50.84 & 52.50 & 51.67 \\
\hline 2 & SP-7 & 7.84 & 8.17 & 8.00 & 36.75 & 38.50 & 37.62 & 00.15 & 00.20 & 00.17 \\
\hline 3 & IRAT 112 & 62.00 & 63.15 & 62.57 & 295.50 & 298.75 & 297.12 & 33.25 & 34.50 & 33.87 \\
\hline 4 & IR 6560 & 45.23 & 46.50 & 45.86 & 210.00 & 215.75 & 212.87 & 27.56 & 28.50 & 28.03 \\
\hline 5 & Sakha 104 & 67.53 & 66.50 & 67.01 & 305.75 & 308.50 & 307.12 & 56.48 & 60.15 & 58.31 \\
\hline 6 & HR 4856 & 71.52 & 70.66 & 71.09 & 320.75 & 326.00 & 323.37 & 67.55 & 65.50 & 66.52 \\
\hline 7 & GZ 7769 & 33.50 & 32.50 & 33.00 & 195.50 & 190.50 & 193.00 & 73.45 & 75.50 & 74.47 \\
\hline 8 & SK-101-7-16 & 17.33 & 14.00 & 15.67 & 43.33 & 36.33 & 39.83 & 0.13 & 0.20 & 0.17 \\
\hline 9 & SK-101-7-17 & 34.33 & 24.00 & 29.17 & 193.00 & 153.67 & 173.34 & 0.13 & 0.17 & 0.15 \\
\hline 10 & SK-101-7-25 & 17.33 & 16.00 & 16.67 & 76.33 & 71.67 & 74.00 & 27.00 & 24.00 & 25.50 \\
\hline 11 & SK-101-7-26 & 3.67 & 2.67 & 3.017 & 18.00 & 5.33 & 11.67 & 53.67 & 46.33 & 50.00 \\
\hline 12 & SK-101-7-35 & 2.33 & 4.00 & 3.17 & 19.33 & 14.00 & 16.67 & 0.13 & 0.17 & 0.15 \\
\hline 13 & SK-101-7-37 & 19.00 & 14.00 & 16.50 & 90.67 & 34.33 & 62.50 & 0.13 & 0.17 & 0.15 \\
\hline 14 & GG-46-6-1 & 2.00 & 1.33 & 1.67 & 16.67 & 4.00 & 10.34 & 0.17 & 0.13 & 0.15 \\
\hline 15 & GG-42-1-2 & 3.00 & 4.00 & 3.50 & 21.67 & 10.67 & 16.17 & 0.17 & 0.17 & 0.17 \\
\hline 16 & GG-42-2-6 & 21.00 & 18.33 & 19.67 & 84.33 & 69.67 & 77.00 & 0.17 & 0.13 & 0.15 \\
\hline 17 & SK-101-Pa-1 & 51.67 & 47.67 & 49.67 & 215.33 & 168.00 & 191.67 & 29.00 & 24.67 & 26.84 \\
\hline 18 & SK-101-Pa-3 & 25.67 & 20.00 & 22.84 & 127.33 & 74.33 & 100.83 & 59.67 & 51.67 & 55.67 \\
\hline 19 & SK-101-Pa-4 & 5.67 & 6.00 & 5.84 & 24.33 & 19.00 & 21.67 & 0.13 & 0.13 & 0.13 \\
\hline 20 & SK-101-Pa-6 & 23.67 & 18.33 & 21.00 & 111.00 & 69.67 & 90.34 & 19.67 & 20.67 & 20.17 \\
\hline & Range & 2.00 & 1.33 & 1.67 & 9.67 & 4.00 & 10.34 & 0.13 & 0.13 & 0.13 \\
\hline & Range & 51.67 & 47.67 & 49.67 & 215.33 & 168.00 & 191.67 & 59.67 & 51.67 & 55.67 \\
\hline & L.S.D $05 \%$ & 3.688 & 4.253 & 3.971 & 10.368 & 9.285 & 9.827 & 4.930 & 4.125 & 4.528 \\
\hline
\end{tabular}

${ }^{*} Y_{1}=2012 \quad Y_{2}=2013 \quad$ Comb= combined 
J. Plant Prot. and Path., Mansoura Univ., Vol. 5 (9), September, 2014

Table (7): Mean performance of some rice genotypes under infection by bakanae diseases at the two seasons 2012 and 2013 and their combined under field conditions.

\begin{tabular}{|c|c|c|c|c|c|c|c|}
\hline \multirow{2}{*}{ No. } & \multirow{2}{*}{ Genotype } & \multicolumn{3}{|c|}{ Bakanae \% } & \multicolumn{3}{|c|}{ Bakanae severity \% } \\
\hline & & $\mathbf{Y}_{1}{ }^{*}$ & $\mathbf{Y}_{2}{ }^{*}$ & Comb. * & $Y_{1}{ }^{*}$ & $\mathbf{Y}_{2}{ }^{*}$ & Comb. * \\
\hline 1 & Sakha 101 & 75.66 & 76.50 & 76.08 & 18.33 & 19.00 & 18.66 \\
\hline 2 & SP-7 & 00.06 & 00.07 & 00.06 & 00.67 & 0.67 & 00.67 \\
\hline 3 & IRAT 112 & 0.00 & 00.0 & 00.0 & 0.00 & 0.00 & 0.00 \\
\hline 4 & IR 6560 & 0.00 & 0.00 & 00.0 & 0.00 & 0.00 & 0.00 \\
\hline 5 & Sakha 104 & 46.55 & 48.60 & 47.57 & 13.33 & 13.00 & 13.15 \\
\hline 6 & HR 4856 & 0.00 & 0.00 & 00.0 & 0.00 & 0.00 & 0.00 \\
\hline 7 & GZ 7769 & 65.23 & 66.25 & 65.74 & 15.67 & 15.00 & 15.33 \\
\hline 8 & SK-101-7-16 & 5.50 & 7.50 & 6.50 & 2.33 & 3.63 & 2.98 \\
\hline 9 & SK-101-7-17 & 8.83 & 9.83 & 9.33 & 4.00 & 3.33 & 3.67 \\
\hline 10 & SK-101-7-25 & 21.67 & 26.67 & 24.17 & 7.50 & 7.83 & 7.67 \\
\hline 11 & SK-101-7-26 & 7.00 & 8.33 & 7.67 & 3.00 & 3.16 & 3.08 \\
\hline 12 & SK-101-7-35 & 0.10 & 0.13 & 0.12 & 0.04 & 0.16 & 0.11 \\
\hline 13 & SK-101-7-37 & 2.50 & 4.50 & 4.75 & 0.81 & 0.16 & 0.49 \\
\hline 14 & GG-46-6-1 & 0.04 & 0.17 & 0.11 & 0.10 & 0.16 & 0.14 \\
\hline 15 & GG-42-1-2 & 0.13 & 0.17 & 0.15 & 0.17 & 0.16 & 0.17 \\
\hline 16 & GG-42-2-6 & 0.13 & 0.17 & 0.15 & 0.16 & 0.16 & 0.17 \\
\hline 17 & SK-101-Pa-1 & 0.17 & 0.17 & 0.17 & 0.16 & 0.16 & 0.17 \\
\hline 18 & SK-101-Pa-3 & 0.10 & 0.17 & 0.14 & 0.16 & 0.13 & 0.15 \\
\hline 19 & SK-101-Pa-4 & 0.13 & 0.20 & 0.17 & 0.16 & 0.16 & 0.17 \\
\hline 20 & SK-101-Pa-6 & 25.67 & 32.83 & 29.25 & 7.66 & 8.00 & 7.83 \\
\hline & Bange & 0.10 & 0.13 & 0.11 & 0.10 & 0.13 & 0.11 \\
\hline & Range & 25.67 & 32.83 & 29.25 & 7.66 & 8.00 & 7.83 \\
\hline & L.S.D $05 \%$ & 2.145 & 1.610 & 2.03 & 0.9320 & 0.8512 & 0.8916 \\
\hline
\end{tabular}


Hammoud S. A. A. and W. S. Gabr

J. Plant Prot. and Path., Mansoura Univ., Vol. 5 (9), September, 2014 J. Plant Prot. and Path., Mansoura Univ., Vol. 5 (9), September, 2014 J. Plant Prot. and Path., Mansoura Univ., Vol. 5 (9), September, 2014 J. Plant Prot. and Path., Mansoura Univ., Vol. 5 (9), September, 2014 J. Plant Prot. and Path., Mansoura Univ., Vol. 5 (9), September, 2014 J. Plant Prot. and Path., Mansoura Univ., Vol. 5 (9), September, 2014 J. Plant Prot. and Path., Mansoura Univ., Vol. 5 (9), September, 2014 J. Plant Prot. and Path., Mansoura Univ., Vol. 5 (9), September, 2014 J. Plant Prot. and Path., Mansoura Univ., Vol. 5 (9), September, 2014 J. Plant Prot. and Path., Mansoura Univ., Vol. 5 (9), September, 2014 J. Plant Prot. and Path., Mansoura Univ., Vol. 5 (9), September, 2014 J. Plant Prot. and Path., Mansoura Univ., Vol. 5 (9), September, 2014 J. Plant Prot. and Path., Mansoura Univ., Vol. 5 (9), September, 2014 J. Plant Prot. and Path., Mansoura Univ., Vol. 5 (9), September, 2014 J. Plant Prot. and Path., Mansoura Univ., Vol. 5 (9), September, 2014 J. Plant Prot. and Path., Mansoura Univ., Vol. 5 (9), September, 2014 J. Plant Prot. and Path., Mansoura Univ., Vol. 5 (9), September, 2014 J. Plant Prot. and Path., Mansoura Univ., Vol. 5 (9), September, 2014 J. Plant Prot. and Path., Mansoura Univ., Vol. 5 (9), September, 2014 J. Plant Prot. and Path., Mansoura Univ., Vol. 5 (9), September, 2014

J. Plant Prot. and Path., Mansoura Univ., Vol. 5 (9), September, 2014 
J. Plant Prot. and Path., Mansoura Univ., Vol. 5 (9), September, 2014 J. Plant Prot. and Path., Mansoura Univ., Vol. 5 (9), September, 2014 J. Plant Prot. and Path., Mansoura Univ., Vol. 5 (9), September, 2014 J. Plant Prot. and Path., Mansoura Univ., Vol. 5 (9), September, 2014

J. Plant Prot. and Path., Mansoura Univ., Vol. 5 (9), September, 2014

J. Plant Prot. and Path., Mansoura Univ., Vol. 5 (9), September, 2014

J. Plant Prot. and Path., Mansoura Univ., Vol. 5 (9), September, 2014

J. Plant Prot. and Path., Mansoura Univ., Vol. 5 (9), September, 2014

J. Plant Prot. and Path., Mansoura Univ., Vol. 5 (9), September, 2014

J. Plant Prot. and Path., Mansoura Univ., Vol. 5 (9), September, 2014

J. Plant Prot. and Path., Mansoura Univ., Vol. 5 (9), September, 2014 